\title{
Sectoral leadership in international competitiveness: the Portuguese
}

\section{case}

\author{
Elsa Cristina Vaz ${ }^{\mathrm{a}, \mathrm{b}}$ \\ ${ }^{a}$ Department of Economics, University of Évora, Largo dos Colegiais 2, \\ 7002-554 Évora, Portugal \\ ${ }^{\mathrm{b}}$ Center for Advanced Studies in Management and Economics of the \\ University of Évora (CEFAGE-UE), Palácio do Vimioso (Gab. 224), Largo \\ Marquês de Marialva 8, 7000-809 Évora, Portugal \\ E-mail:elsavaz@uevora.pt
}

\begin{abstract}
The purpose of this article is to identify the type of labour and the sectors where labour productivity should be improved to elevate the international competitiveness of Portugal. A static multisectoral general equilibrium model, with multinational and single-country versions, is used. This model permits the identification of sectors that are leaders in competitiveness improvement. In some countries, traditional export sectors are expected to assume this role, whereas the suppliers of intermediate goods possess the potential to fulfil this function in other countries. The results of this study show that the choice of sector and the type of labour are crucial for improving the international competitiveness of the Portuguese economy. The criterion used to measure competitiveness also has an important role. Whereas multifactor productivity is especially increased when the promotion of labour competencies occurs in import and export sectors, population welfare has a greater impact, with the generalized improvement of unskilled labour competencies.
\end{abstract}

Keywords: general equilibrium models; competitiveness; productivity; skills

JEL Classification: D58; J24; D24

\section{Introduction}

The last two enlargements of the European Union (EU) have created new problems for the Portuguese economy by challenging its performance and future development. Many politicians, as well as academics, strongly recommend that Portuguese firms become more competitive in international markets, especially now that new member states enjoy the same degree of accessibility to the European market as Portugal and have some advantages in attracting new investments. However, improving Portugal's competitiveness is possible only if the labour force becomes more productive. Moreover, the concept of the "competitiveness of an economy' used by European institutions and other international institutions implies a 'significant and sustainable growth of productivity'. Thus, improving productivity in Portugal is key to the success of its economy.

In this study, we test two alternatives that may lead to an increase in labour productivity: the improvement of labour qualifications and the enhancement of labour competencies. When workers invest in their qualifications, they are transferred to the qualified 